\title{
A FRAMEWORK FOR UNDERSTANDING CELLULAR MANUFACTURING SYSTEMS
}

\author{
Sílvio do Carmo Silva, Anabela Carvalho Alves \\ Minho University, Campus de Gualtar, 4710 - 057 - Braga, Portugal \\ phone:+351+253604745, fax: +351253604741, e-mail scarmo@dps.uminho.pt \\ Minho University, Campus de Azurém, 4800 - 058 - Guimarães, Portugal \\ phone:+351+253 510260,fax:+351 253 510268, e-mail anabela@dps.uminho.pt
}

\begin{abstract}
Many practical benefits, such as superior quality of products and short manufacturing lead times, are usually associated with Cellular Manufacturing. These and other benefits can lead to important competitive advantages of companies. However, to fully achieve these benefits there is a need for an evolution from the traditional concept of CM to the more comprehensive one, which we call Product Oriented Manufacturing. Here systems are dynamically reconfigured for total manufacturing of complete products, not parts only.

In this paper, we make a contribution to better understand the nature of cells and POM Systems. Thus a classification framework is presented of the different types of cells that might be formed and seen as building blocks for POMS.
\end{abstract}

\section{INTRODUCTION}

Traditionally a manufacturing cell has been identified as a system dedicated to the manufacture of a family of identical parts. The manufacture based on a setting of such cells is usually referred to as Cellular Manufacturing.

A more comprehensive definition of a manufacturing cell points to a manufacturing system that groups and organizes the manufacturing resources, such as people, machines, tools, buffers, and handling devices, dedicated to the manufacture of a part family, or the assembly of a family of products, with identical or very similar manufacturing requirements. Therefore important economies of scale can be obtained producing for economies of scope, i.e. for a variety of products.

This approach of identical or very similar processing of similar objects is known as Group Technology (GT) (Gallagher, 1973). It is for this reason that manufacturing systems based on cells are frequently associated with GT.

The problems to be solved in Cellular Manufacturing Systems (CMS) can be classified in cell design and cell operation problems.

Arvindh and Irani (1994) identified four classes of problems to be solved in the design of cellular manufacturing cells, namely: machine group and part family formation, machine duplication, intra-cell layout and inter-cell layout. These 
authors argue that such problems are closely interrelated and must be solved integrated and iteratively. They go on proposing a method for cell design based on this integrated approach. Nevertheless, most methods and models that have been proposed only solve one or some of the identified problems in a manner that do not take in consideration all the referred interrelationships [(Suresh, 1998), (Moodie, 1995)]. Due to this, the results from such methods or models tend to be somewhat inefficient and, in many cases, of little practical value.

In addition to the design problems pointed out by Arvindh and Irani, operation problems must be solved. These have to do mainly with production control including scheduling. For these a variety of methods have also been identified [(Suresh, 1998), (Moodie, 1995)].

CMS are rarely designed having in consideration the need for parts production coordination for making complete products or meeting customer orders of end items. Thus, the need for quick response to customer requirements, which is recognized as an important strategic objective, is not taken explicitly in full account. This limitation however has been addressed in recent years through a variety of systems interlinking a number of cells. A paradigmatic example of this is the Quick Response Manufacturing system as referred by Suri (1998).

\section{GENERIC CONFIGURATIONS OF MANUFACTURING SYSTEMS}

Traditional Manufacturing Systems may be classified in two major classes, Figure 1: Functional Oriented Manufacturing Systems (FOMS) and Cellular Manufacturing Systems (CMS). The former are characterized by the functional organization, frequently also referred to as process organization (Burbidge, 1996). Here, work flows between functional departments or shops according processing requirements. Cellular Manufacturing can be seen as a simplified form of product organization that carries out production in manufacturing cells.

Usually a variety of different jobs, i.e. parts and components, or even one-of-akind jobs, are concurrently manufactured in FOMS in a complex network of workflows. Due to this and frequent system overloading for improving system utilization, work in process and manufacturing lead times are usually high and achieving due dates can be difficult and unpredictable. Trying to reduce drawbacks of FOMS through inventories can be acceptable in some cases but this can be costly in varying and dynamic customer demand environments.

CMS are organizationally very different. For achieving its purpose a CMS i made of complementary workstations at each stage of processing, according to the need of the family of similar jobs to be manufactured.

Important similarities of jobs of a family, in the context of CMS, have to do not only with the share of same manufacturing resources and processes but also commonly with similarity of sequence of operations, materials, geometry, tolerances and volume of production. This makes identical the manufacturing, including handling, transport and storage, of apparently different jobs. 
Due to the product oriented nature of CMS, not only higher productivity, lower WIP, lower throughput time and better production control can be expected but also higher volumes of production can be better dealt with than within FOMS. Because of this, CMS can be seen as instrumental to achieve what Skinner (1974) defines as a focused factory.
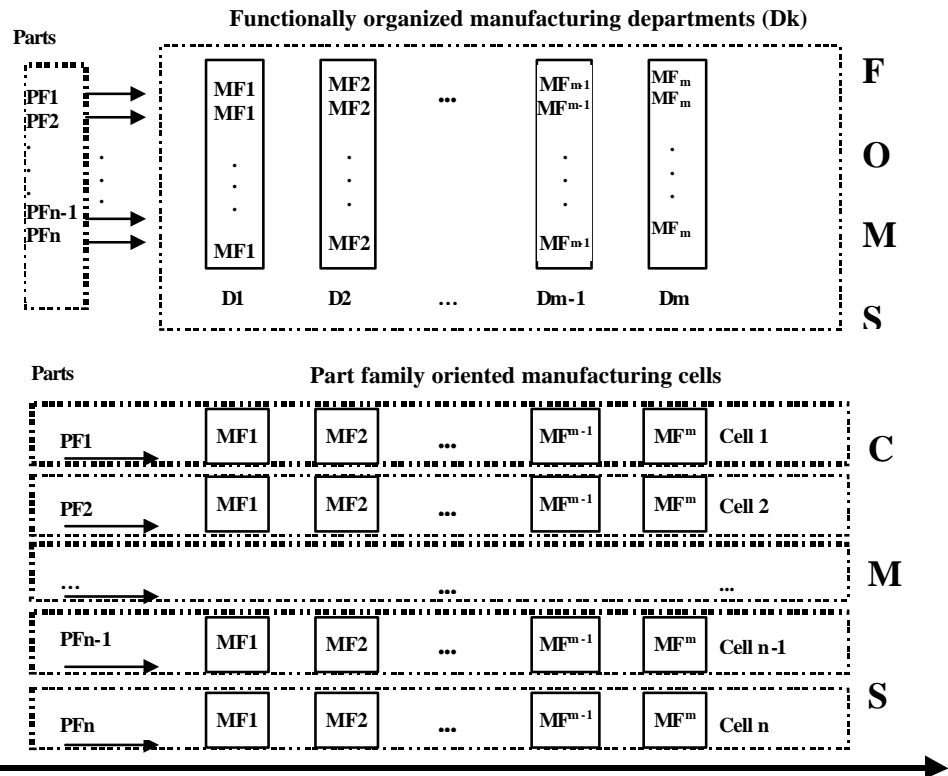

Manufacturing Functions

PFi - the similar set of parts to manufacture or products to assemble of family Fi

Figure 1 - A generic and interrelated view of a FOMS and a CMS

\section{CONCEPTUAL MANUFACTURING CELL CONFIGURATIONS}

Five different flows of work can be identified in a manufacturing cell, namely direct, direct with bypassing, inverse, inverse with bypassing and repetitive, Figure 2.

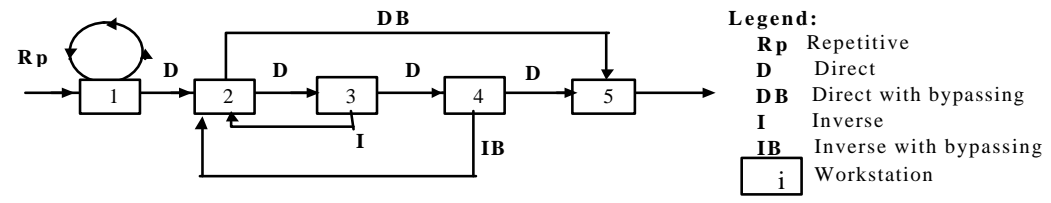

Figure 2 - Workflows in manufacturing cells (adapted from Aneke, 1986) 
Repetitive flow means that the same workstation is required in sequence twice or more times by the same job. It is the combination of these flows that differentiate cell configurations.

\subsection{Basic Cell Configurations}

Workflow in cellular manufacturing should preferably be direct, with every job having exactly the same number of operations. We name a cell with these characteristics as a Pure Flow Cell (PFC). If the number of operations is not equal for all jobs processed in direct flow and, additionally, bypassing flow is allowed, then we could say, that we have a more general concept of flow cell and call it General Flow Cell (GFC). In the more general case we can consider unrestricted direction of the flow of work and call the cell General Cell (GC). Therefore, not only direct with bypassing, but also backtracking or inverse and repetitive flow can be allowed. This GC cell case applies when both the number of operations and operations sequences are not identical for all parts of the family. Clearly this situation is more difficult to manage and explore than the much simpler direct flow cell, with or without bypassing flow.

In addition to the cell configurations above referred we identify the Single Workstation Cell (SWC) configuration. Clearly, from workflows shown in Figure 2 the repetitive is the only one that might be available in such a cell. This does not exclude the possibility of workstation intra-flow, which may be seen as a repetitive flow within the same workstation, taking place between its parallel processors, if they exist.

To the four configurations identified we call Basic Cell Configurations, Figure 3.

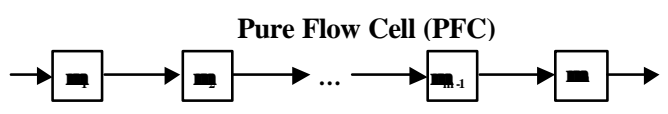

Single Workstation

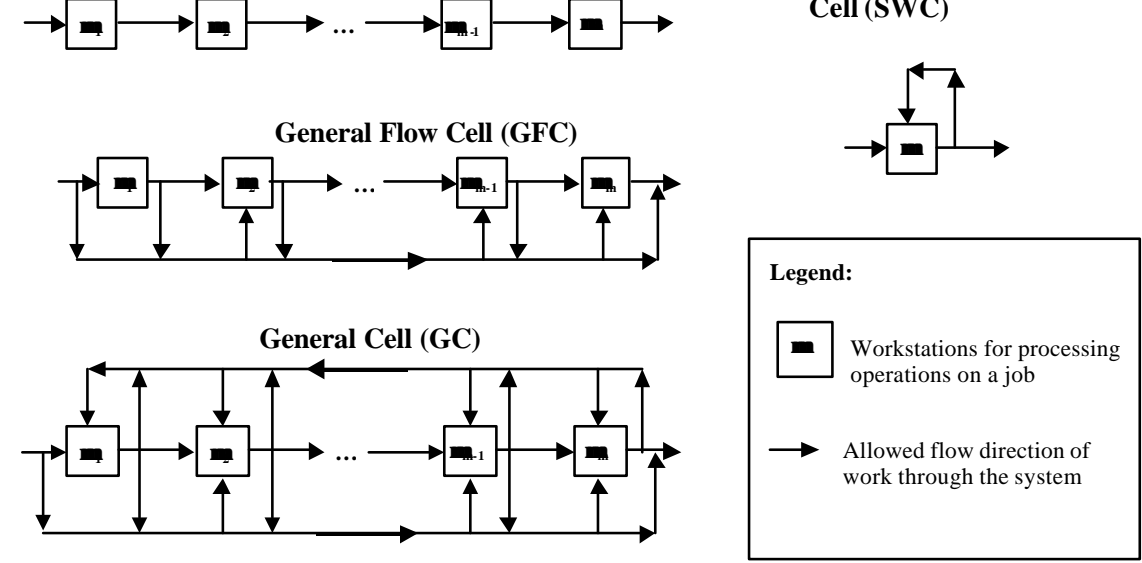

Figure 3 - Schematic representation of the four Basic Cell Configurations

These have their counterparts in the theory of scheduling. Thus, the PFC, the GFC and the GC may be respectively associated with pure flow lines, general flow lines and general shops [(Baker, 1974), (Brucker, 1995), (Blazewicz, 1996)]. 
Although a cell may work as a general shop, or as its job-shop instance, the tendency is to avoid such situation because this would require complex control at various levels of production.

Some authors, talking about cells focus only on the flow type configurations. They refer cells and lines as being identical concepts. In fact the distinction between the two can be difficult to make. Such distinction seems to be based more on matters of system operation and manning than on the nature of the flow of materials. Thus, for instance, such difficulty is underlined by Schonberger (1983) when says that "... cells and production lines are cut out of the same cloth" and by Black e Schroer (1988) who state, comparing with lines, that "the unique feature of a cell is that the cycle time is not dependent on the manufacturing time of a particular machine". Apparently it seems that cells are different from balanced manufacturing or assembly lines. However there is no reason why we cannot have balanced flow lines manufacturing a family of parts or assembling a group of similar products, which is the same as to say balanced cells.

The SWC configuration is a more general case than single processor or parallel processor systems referred in scheduling theory. However a strong approximation exists. This is because the workstation may in fact be provided with a single processor or with a few parallel processors. However, as referred above, they behave as a more general system because repetitive work is considered and inter processor flow of materials is allowed, for instance, when more than an operation of a job is to be carried out in the same workstation having parallel processors.

\subsection{Non - Basic Cell Configurations}

A typical problem in the formation of cells is the unavailability of enough replicated manufacturing resources, i.e. machines, to be allocated to different cells. Thus, to solve the problem two strategies are usually followed. The first looks for enlarged part families as a way of sharing scarce resources, which are then allocated to fewer cells. The main aim of this strategy is to keep manufacturing of the entire spectrum of parts of each family in its own cell creating this way independent and autonomo us cells. We could say that there is a gain in autonomy but a probable loss in cell efficiency. In fact the similarity within such enlarged families, as a result, is reduced making manufacturing more complex.

The second strategy configures two logics. In one, cells share their resources with other cells, allocating load to process parts belonging to families initially allocated to other cells. In this case inter-cellular flow of parts takes place. In the second logic, some resources are independent and shared by more than one cell. Irani, Cohen and Cavalier (1992) call this arrangement hybrid layout considering that shared resources are organized by function. In both logics, however, we can observe to exist shared equipment between cells. So we also interpret these cells as shared cells. The result in both cases is disturbed flow of work in any shared cell. So, the disturbing behaviour of work within cells is similar in both referred logics. This is probably the most important factor affecting operational efficiency of shared cells. Due to this we do not distinguish between hybrid layout and shared cells, calling any cell involved in intercellular workflow Shared Cell, Figure 4. 


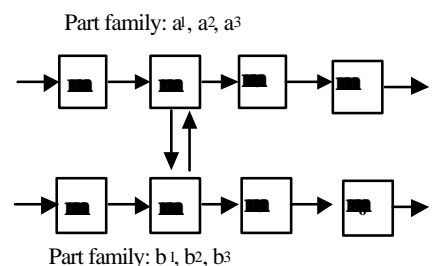

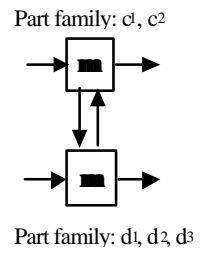

a)

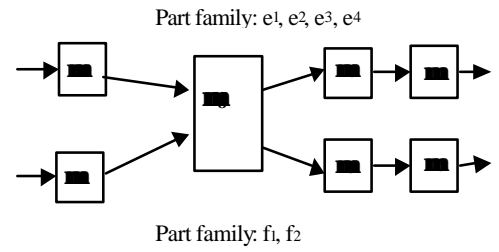

b)

Figure 4-Schematic representation of shared cells: a) inter-cellular workflow between shared cells b) shared cells in a hybrid layout

The set of Basic and Non-Basic cells we call Conceptual Cells, Figure 5.

An alternative name for the Conceptual Cells could be based on the independence of processing. In this case we could say that basic configurations correspond to independent cells and the non-basic to dependent cells.

\begin{tabular}{|l|l|c|}
\hline \multirow{3}{*}{} & Single Workstation Cell & SWC \\
\cline { 2 - 3 } & Pure Flow Cell & PFC \\
\cline { 2 - 3 } & General Flow Cell & GFC \\
\cline { 2 - 3 } & General Cell & GC \\
\hline \multirow{3}{*}{$\sum_{\substack{*}}^{*}$} & Shared Single Workstation Cell & SSWC \\
\cline { 2 - 3 } & Shared Pure Direct Flow Cell & SPFC \\
\cline { 2 - 3 } & Shared General Flow Cell & SGFC \\
\cline { 2 - 3 } & Shared General Cell & SGC \\
\hline
\end{tabular}

Figure 5 - Conceptual Cells in Cellular Manufacturing

\subsection{Virtual Manufacturing cells}

Virtual Manufacturing Cells, VMC, is a concept initially reported in 1982 by Simpson, Hocken and Albus, according to Ratchev (2001), and by McLean, Bloom and Hopp (McLean, 1987). VMC can be seen as dynamic software arrangements of machines or workstations, of large facilities, to be operated under cellular manufacturing for a given time period without re-arranging their physical layout. The advantage of virtual cells stems from the fact that dynamic virtual cell reconfiguration can easily and frequently be carried out at minimum cost. This is important under market changing environment to suit manufacturing changing requirements when and where frequent changes of a physical setting of the manufacturing equipment are uneconomical and impractical or cannot take place.

VMC may be configured as virtual cell instances of Conceptual Cells.

Ratchev (2001) put forward an approach, quite different from conventional ones, for the formation of virtual manufacturing cells, of the shared class, in a machining environment. The approach based on machine processing capabilities can derive a set of virtual machining cells and the matching part families based on a processing plan for each part. These plans, expressed in the so-called Resource Elements (RE) 
of the machine shop permits alternative use of machines since more than a machine is likely to offer the same RE.

\subsection{Resource Combination and Flexibility of Workstations}

The identified Conceptual Configurations embraces quite a few instances that have to do with resource combination and flexibility of workstations. Thus the nature and quantity of manufacturing resources let them be main resources, such as machines, or auxiliary resources, such as operators and tools involved in each workstation, originates different instance types of each Conceptual Configuration and puts different problems to be solved at both design and operation of CMS.

Thus, the number of operators and the level of replicated auxiliary equipment, such as tools, together with their dynamic utilization within cells may substantially affect, not only the cell capacity and manufacturing flexibility, but also the manner how cells can be operated. Therefore auxiliary resources largely determine the performance level of manufacturing cells (Silva, 1997, 1995, 1988).

Moreover, cell efficiency and effectiveness, being highly dependent on cell operation, is also influenced by the configurations of each workstation in a cell. Workstations may be configured in different ways according to manufacturing requirements and objectives. They may be simple, provided with a single machine to carry out a single manufacturing function or be more complex involving three other situations which may be combined, namely having a) parallel processors, b) multiple resources or processors and c) multifunction processors.

Flow shops having parallel processors have been referred to as Flexible Flow Shops (Pinedo, 1995) or Hybrid Flow Shops (Elmaghraby, 1997). So we could consider a flexible flow cell to be a flow cell with parallel processors. The need for parallel processors may be mainly justified on capacity grounds, operational reliability and flexibility.

Many times work must be carried out simultaneously using a number of resources at a workstation. These may include, for instance, machines, tools and operators. These systems are referred in the literature as multiprocessor task systems for which a class of scheduling problems is identified [(Brucker, 1995), (Blazewicz, 1996)]. Again instance types of Conceptual Cell Configurations having multiprocessor tasks can be considered which may be called multiprocessor task cells.

Further, workstations may be provided with flexible machines capable of carrying out a range of different operations, usually through changing manufacturing aids such as tools, numerical control programs and fixtures. This is typical in Flexible Manufacturing Systems and Cells (Silva, 1988). Cells with flexible machines can be named multifunction processor cells. A class of scheduling problems for Multifunction Processor Systems is identified in the literature (Brucker 1995).

From above we can conclude that having in consideration the characteristics of workstations we can arrive to several variations on the Basic and Non-basic Conceptual Cell Configurations. Moreover if flexibility is explored through dynamic utilization of manufacturing resources and autonomous cells are interlinked to achieve coordinated production of end items we can arrive to several system 
concepts widely referred and used in practice, which we classify under the heading of Product Oriented Manufacturing Systems (POMS).

\section{PRODUCT ORIENTED MANUFACTURING SYSTEMS - POMS}

Although CMS can have a beneficial impact on manufacturing operations of an enterprise, the full benefits of such product-oriented approach to production can only be realized when overall production is considered. This means that, good production of parts or the assembly of products alone does not mean necessarily effective advantages for a company as a whole. It is important that customer full orders are quickly satisfied under high quality and good use of manufacturing resources. To effectively answer these challenges CMS must evolve to POMS. A POMS system is a set of interlinked manufacturing resources or cells simultaneously and coordinately addressing, the manufacturing of a product, and therefore all its components, or a range of similar products, including all assembly work necessary. A product may be simp le, like a part, or complex, having a product manufacturing structure, involving several levels. This may be represented in a multilevel bill of materials (BOM). When the product is simple, a POMS may simply take a form of a cell. Otherwise it configures a coordinated set of interlinked cells.

This coordination of work among manufacturing resources or cells is one of the most distinguishing aspects of POMS. A set of cells that do not work under such a coordination setting, across the requirement of all items and tasks of the overall and final product, is not a POMS.

An enlarged view of the POMS concept includes logistic operations, mainly when production resources are distributed in space. Truly, to be successful, production under this concept must be able to fully and dynamically consider and involve resources available to a company, over a time period, locally or globally, either belonging to its own or to potential production partners.

Dynamic reconfiguration of POMSs, under changing market requirements is, most probably, necessary. This necessity is also justified due to the dedicated nature of POMSs to specific mix of products which, changing over time, calls for new arrangements to ensure high levels of operational performance.

POMS may be built by putting together, in a localized site, manufacturing means or resources that may be physically dispersed or alternatively, when such is not possible or is uneconomical, by organizing them in virtual POMS. For this a methodology should be applied that deals integrated and iteratively with the many problems of POMS design. Silva and Alves (2001) have made a contribution in this direction.

Quite a few variations of the POMS concept have been put forward in recent years. All of them may derive their configurations fom the Conceptual Cells presented in this work. Some of the proposed and realized POMS draw upon a range of technologies and methods, not available in the past, in domains such as computer science, information systems, electronic communications, including intranets and Internet, mechatronics and company internal and external logistics. Such systems, 
some of which very familiar in practice, are known under names such as focused factory, just-in-time, lean, linked-cell, OPIM, quick response, flexible, reconfigurable and virtual systems [(Silva, 2001), (Monden, 1983), (Lewis, 2000), (Black, 1991), (Suri, 1998), (Putnik, 1995), (Chen, 1998) (Tempelmeier, 1993), (Mehrabi, 2000), (Drolet, 1996), (Lee, 1997) (Iwata, 1995), (Camarinha-Matos, 1999) and (Ratchev, 2001)].

\section{CONCLUDING REMARKS}

To keep up with increasing and changing market demands of today and tomorrow, companies must be able to efficiently manufacture and quickly deliver good quality products to customers. To achieve this today companies cannot rely on traditional organization and operation of systems based on functional departments. Moreover, cellular manufacturing based on uncoordinated or loosely coordinated manufacturing cells is also inappropriate. Present requirements indicate that a more holistic approach to manufacturing is necessary. This can be achieved through Product Oriented Manufacturing Systems (POMS) dynamically built of cells or manufacturing resources, local or globally available, which must be interlinked and closely coordinated for the total production of complete products, not parts only. These products may preferably bear manufacturing similarities. Although a localized physical set-up for such purpose should be sought, POMS are likely to be more dependent on virtual reconfiguration when resources are dispersed or are uneconomical to rearrange.

Faced with apparently different recent and past manufacturing systems, such as focused factory, just-in-time, lean, linked-cell, OPIM, quick response, flexible, reconfigurable and virtual systems, we can observe that, in different degrees, they all have the underlined characteristic of being product oriented systems as defined in this work. This is why we consider them to be instances of the general POMS concept.

A framework of conceptual cells is presented in this work, which can contribute for a better understanding of cellular manufacturing as instrumental for helping in the design and operation of POMS. This framework resumes cells to two sets, the basic and non-basic cells, for which virtual counterparts can be considered. Further, the nature of cell workstations is explained having in consideration manufacturing resource combination and flexibility.

\section{REFERENCES}

1. Aneke NAG, Carrie AS. A design technique for the layout of multiproduct flowlines. International Journal of Production Research, 1986; 24:471-481.

2. Arvindh B, Irani SA. Cell formation: the need for an integrated solution of the problems. Int. Journal of Production Research, 1994; 32: 5.

3. Baker, KB. Introduction to Sequencing and Scheduling. John Wiley and Sons, 1974.

4. Black, JT. The Design of the Factory with a Future. McGraw-Hill, 1991.

5. Black JT, Schroer BJ. Decouplers in Integrated Cellular Manufacturing Systems, Journal of Engineering for Industry, 1988; 110:77. 
6. Blazewicz J, Ecker KH, Pesch E, Schmidt G, Weglarz J. Scheduling Computer and Manufacturing Processes. Springer Verlag, Heidelberg, 1996.

7. Brucker, P. Scheduling Algorithms. Springer, 1995.

8. Burbidge, JL. Production Flow Analysis for planning Group Technology. $1^{\text {a }}$ publicação 198, Oxford: Clarendon Press, 1996.

9. Camarinha-Matos LM, Afsarmanesh H. "The Virtual Enterprise Concept". In Working Conference on Infraestructures for Virtual Enterprises (PRO-VE'99), L. M. Camarinha-Matos and H. Afsarmanesh, ed., Kluwer Academic Publishers, 1999.

10. Chen, F. Frank. Flexible production systems for the apparel and metal working industries: a contrast study on technologies and contributions. Int. J. of Clothing Science and Technology, 1998; 10:1.

11. Drolet JR, Montreuil B, Moodie CL. Empirical Investigation of Virtual Cellular Manufacturing System. Symposium of Industrial Engineering - SIE'96, 1996.

12. Elmaghraby SE, Karnoub RE. "Production Control in Hybrid Flowshops: An example from textile Manufacturing". In The Planning and Scheduling of Production Systems, A. Artiba and S. E. Elmaghraby, ed., Chapman and Hall, 1997.

13. Gallagher CC, Knight WA. Group Technology. Butterworths, 1973.

14. Irani SA, Cohen PH, Cavalier TM. Design of Cellular Manufacturing Systems. Transactions of the ASME, 1992; 114.

15. Iwata K, Onosato M, Teramoto K, Osaki S. A Modelling and Simulation Architecture for Virtual Manufacturing Systems. Annals of the CIRP, 1995; 44:1.

16. Lee, KI. Virtual Manufacturing System - A Test Bed of Engineering Activities. Annals of the CIRP, 1997; 46:1.

17. Lewis, MA. Lean production and sustainable competitive advantage. Int. J. of Operations \& Production Management, 2000; 20; 8, 959-978.

18. McLean CR, Brown, PF. "The Automated Manufacturing Research Facility at the National Bureau of Standards". In New Technologies for Production Management systems, H. Yoshikawa e J. L. Burbidge, ed., Elsevier Science Publishers B. V. North - Holland, 1987.

19. Mehrabi MG, Ulsoy AG, Koren Y. Reconfigurable Manufacturing Systems: Key to Manufacturing. Journal of Intelligent Manufacturing, 2000; 11: 403-419.

20. Monden, Y. Toyota Production System. Industrial Engineering and Management Press, Institute of Industrial Engineers, 1983.

21. Moodie C, Uzsoy R, Yih Y. Manufacturing Cells - A System Engineering View. Taylor \& Francis, 1995.

22. Pinedo, M. Scheduling - Theory, Algorithms and Systems. New Jersey: Prentice-Hall Inc, 1995.

23. Putnik GD, Silva SC. One Product Integrated Manufacturing. In Balanced Automation Systems, L. M. Camarinha-Matos, H. Afsarmanesh, eds. Chapman \& Hall, 1995.

24. Ratchev, SM. Concurrent process and facility prototyping for formation of virtual manufacturing cells. Integrated Manufacturing Systems, 2001; 12: 4, 306-315.

25. Schonberger, RJ. Plant Layout Becomes Product-Oriented with Cellular, Just-In-Time Production Concepts. Industrial Management, 1983, 66-70.

26. Silva, SC. An Investigation into tooling requirements and strategies for FMS operation. PhD Thesis. LUT, UK, 1988.

27. Silva SC., Alves, AC. SPOP - Sistemas de Produção Orientados ao Produto. Células Autónomas de Produção - TeamWork'2001 Conferencia, Lisboa, 2001

28. Silva SC, Putnik GD. "Gestão de Produção - Influência dos Meios Auxiliares na Flexibilidade Operatória dos Sistemas Flexíveis de Manufactura", Seminário COMET - Gestão da Produção em Tempo Real na Indústria do Vestuário, Universidade do Minho, Guimarães, 1995.

29. Silva, SC. "Analytical Assessment of Tooling Requirements for FMS Design and Operation". In Reengineering for Sustainable Industrial Production, L. M. Camarinha-Matos, ed., Chapman \& Hall, 1997.

30. Silva SC, Alves AC. Uma Metodolo gia para o Projecto de Sistemas de Produção Orientados ao Produto. VII Int. Conf. on Industrial Engineering and Operations Management, Brasil, 2001.

31. Suresh NC, Kay JM. Group Technology and Cellular Manufacturing - State of the Art Synthesis of Research and Practice. Kluwer Academic Publishers, 1998.

32. Skinner, W. The focused factory. Harvard Business Review, 1974.

33. Sury, R. Quick Response Manufacturing - A Companywide Approach to Reducing Lead Times. Oregon: Productivity Press, 1998.

34. Tempelmeier, H, Kuhn, H. Flexible Manufacturing Systems. John Wiley \& Sons, Inc., 1993. 